\title{
MODEL FOR MEASURING CUSTOMER LOYALTY TOWARDS A SERVICE PROVIDER
}

\author{
Ilona SKAČKAUSKIENE் ${ }^{1}$, Neringa VILKAITĖ-VAITONÉ², \\ Sergej VOJTOVIC ${ }^{3}$
}

\author{
${ }^{1,2}$ Department of Social Economics and Management, Vilnius Gediminas Technical University, \\ Sauletekio al. 11, 10223 Vilnius, Lithuania \\ ${ }^{3}$ Department of Management and Development of Human Resources, University of Alexander \\ Dubcek, Studentska 3, 91150 Trenčín, Slovakia

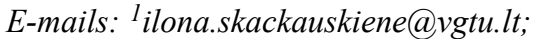 \\ ${ }^{2}$ neringa.vilkaite-vaitone@vgtu.lt (corresponding author); \\ ${ }^{3}$ sergej.vojtovic@tnuni.sk
}

Received 23 February 2015; accepted 22 October 2015

\begin{abstract}
The paper aims to create a valid model for measuring customer loyalty towards a service provider. Principal solutions for designing a model of loyalty measurement have emerged from the clarified role of customer loyalty and evaluation problems. The worked out solutions include selecting a proper concept (1), loyalty specification (2), determining a period necessary for loyalty measurement (3), differentiation of loyalty measurement depending on accessible data (4) and measuring a stage of loyalty (5). The conducted research referred to an example of a catering company, thus adopting an original mathematical model for the empirical measurement of customer loyalty. The obtained results have revealed that the loyalty of the customers of the investigated service provider is of an intermediate level. The findings have also showed the superiority of the proposed model for measuring the state of customer loyalty and for obtaining better solutions to the development of customer loyalty in the service industry.
\end{abstract}

Keywords: customer loyalty, measurement of customer loyalty, service loyalty, service business, purchase value, purchase frequency.

JEL Classification: M31.

\section{Introduction}

Customer loyalty is important for service companies striving for survival and strengthening of their competitiveness. Customer loyalty plays a crucial role in ensuring competitive advantage of a service provider because it is ten times less expensive for a business to retain its existing customers than to acquire new ones (Roy 2011). In addition, customer loyalty creates prerequisites for an increase in the market share, income, and profit, strengthens business development and the image of the service provider (Terblanche, Boshoff 2010). Therefore, the development of customer loyalty becomes an 
important aim of service organisations. However, service loyalty can be developed only when measured. Debates on the selection of the model for measuring customer loyalty started more than thirty years ago. Nowadays, this issue has become an important object of research on loyalty in theory and practice, as knowledge of customer loyalty leads to proper reaction, intense competition, market saturation and internationalisation.

In recent years, rather intense research on customer loyalty towards a service provider has been carried out (Chen, Cheng 2012; El-Manstrly, Harrison 2013; Yong-Jae et al. 2013; Chou et al. 2014; Khan, Fasih 2014; Yang et al. 2014; Zhang et al. 2014). Despite the abundance of the studies performed, until now, no universal model for measuring customer loyalty in service organisations has been accepted. It is essential to find a proper and reliable tool for measuring customer loyalty since measurement sorts out the most profitable customers.

The carried out research is aimed at creating a valid model for the measurement of customer loyalty towards a service provider. The model should correspond to the modern needs of service organisations and should be flexibly used. An investigation into the academic literature, logic and synthesis together with statistical data analysis and correlation methods have been applied thus to conduct a case study in order to achieve the aforementioned aim.

\section{Literature review}

The construct of customer loyalty first appeared in the 1940s. Since then, loyalty has been treated as a measurable category. The following three dimensions of loyalty, including behavioural loyalty (referred to the market share), attitudinal loyalty (emphasis on the brand preference) and multidimensional loyalty integrating the concepts of behaviour and attitude have evolved (Dick, Basu 1994; Oliver 1999; Chadha, Kapoor 2009; Worthington et al. 2010; Terblanche, Boshoff 2010).

According to R. L. Oliver (1999), behavioural loyalty is simply a customer behaviour. He argues that loyalty has always been and continues to be defined, in some circles, as a frequency of repeated purchase or a relative volume of purchasing of the same brand. The posture of the cognitive school that forms a major part of marketing research serves as the basis for attitudinal loyalty; this approach emphasises psychological aspects of loyalty development. The attitudinal approach is focused mainly on brand recommendations (Chadha, Kapoor 2009), resistance to superior products (Worthington et al. 2010; Terblanche, Boshoff 2010), willingness to pay the price premium and repurchase intention. The concepts of the attitude and behaviour have been integrated by multidimensional loyalty. A. S. Dick and K. Basu (1994) made a significant contribution to the formation of the approach to multidimensional loyalty: loyalty was conceptualised as a combination of a favourable attitude and behaviour or repurchases. Repeated purchases are related to behavioural loyalty and include the continued purchase of the same product. An attitude towards a product shows the customer opinion on a specific product. A. S. Dick and K. Basu (1994) supposed that the attitude has to be treated as a cause of repeated purchases. This has been also confirmed by S. Hart et al. who concluded that loyalty is a function of attitude-manifested behaviour (1999). 
Nowadays, irrespectively of the concept, on which it is based on, loyalty is acknowledged as the most important driver of the long-term success of a service organisation. As customer loyalty becomes an important aspect of service organisations in the modern business environment, the measurement of customer loyalty requires special attention and respective resources. Scientists mention a number of metrics for measuring customer loyalty based on behaviour, the attitude or both, the repurchase rate, the share of requirements, the willingness to pay the price premium and other measures (Roy 2011; Topcu, Duygun 2015).

However, the majority of them are suitable only for the use in certain cases and specific situations. The current methodological package is too scarce and not developed enough for its practical application in the regime dictated by the business (Terblanche, Boshoff 2010; Worthington et al. 2010). Thus, despite an active interest in the concept of loyalty, progress in research on methods and means measuring customer loyalty is rather limited in terms of methodological validity and practical applicability.

For the meantime it is not clear which concept of loyalty should be followed therefore it is hard to estimate customer loyalty. As it has already been mentioned, the methods measuring customer loyalty towards a service provider can be classified into behavioural, attitudinal and multidimensional. The researchers' position regarding the concept of proper loyalty still lacks conformity, because, while based on different concepts, slightly varying or even contradictory results are obtained: a customer estimated to be loyal in one survey becomes a switcher in the other. This limits the possibilities of comparing the results of separate studies. Practitioners are also uncertain about which concept of measuring customer loyalty is the most superior.

The impartial and valid measurement of customer loyalty towards a service provider is also limited by the non-unified content of loyalty. This is indicated by a huge variety of loyalty measures, including the cycle of repurchases, the intensity of purchases, a period of use, a period of customer membership in the loyalty programme, the number of customers, net profit, etc. Until now, it has been still unclear, which customer loyalty elements should be measured in order to assess analogical customer loyalty under identical or at least similar circumstances. Apart from this, it is unknown if all elements equally affect customer loyalty.

The measurement of customer loyalty is also encumbered by the problem of selecting a period. The academic literature suggests using the periods from 6 to 24 months ( $R e-$ inartz et al. 2008; Uncles et al. 2010). It should be noted that the maximum period (24 months) may be absolutely insufficient for measuring loyalty towards some very rarely used services. This means that the need to define an individual period is presupposed by the characteristics of purchase frequency and value. A well-founded assessment of the survey period should be based on the average inter-purchase cycle for the service (Wheat, Morrison 1990). In the cases of consumables, the research period should usually include the purchasing history of at least 18-24 months. In the cases of rarely used services (for example, related to motor vehicles, electronic devices), it would be expe- 
dient to include the available entire history of purchasing, which means that, in some cases, it is impossible to obtain all data to perform precise analysis.

The lack of the differentiation of customer loyalty measurement according to data accessibility situations is an additional problem of measuring customer loyalty towards a service provider. Scientists have distinguished a number of loyalty measurement methods; however, frequently, due to limitations on data accessibility, they are suitable for use only in certain cases and in specific situations (Bennett, Rundle-Thiele 2002). Such methods lack versatility in terms of their practical applicability. This means that, should the service provider fail to collect data required for the practical application of the method for measuring customer loyalty, the application of the selected technique becomes very limited. To eliminate this problem, it would be expedient to formulate loyalty measurement options in different data accessibility situations.

Customer loyalty is determined by a wide spectrum of drivers (Calin 2013; Kumar et al. 2013; Narteh 2013; Yong-Jae et al. 2013), but a set of those determining customer loyalty are differentiated by loyalty participants, and the impact the drivers have on loyalty is lacking. Even a partial identification of the drivers determining customer loyalty would help organisations to solve the problems of customer turnover more efficiently thus creating reasonable and appropriate solutions for loyalty development.

The identified problematic aspects of assessing customer loyalty undoubtedly encumber the measurement of customer loyalty as well as highlight the insufficiency of the current methodological potential for the needs of modern-day practices in business. Its fragmentary nature has presupposed the need to prioritise the creation of the model essentially based on new principles.

\section{Model}

\subsection{Concept of measuring customer loyalty}

Measurement of customer loyalty should be based on the behavioural concept that is more common than the attitudinal concept in research practice (Casalo et al. 2007; Tuu, Olsen 2010). The popularity of this dimension has been determined not only by the weaknesses of attitudinal loyalty but also by the influence of behavioural loyalty on the income and profit of an organisation (Chao 2008). In addition, behavioural loyalty matches the particularities of services (Seto-Pamies 2012). It is sufficiently informative, objective and reasonable regarding the aspect of available data (Uncles et al. 2010; Worthington et al. 2010). Despite the superiority of behavioural loyalty over attitudinal loyalty, loyalty measurement is not and cannot be isolated from the customer attitude. Behavioural loyalty indirectly integrates attitudinal loyalty since loyal behaviour is impossible without a customer-friendly attitude towards an organisation and its services (Casalo et al. 2007). After the formation of appropriate intentions and their active mode, attitudinal loyalty turns into behavioural loyalty, or otherwise into the result of attitudinal loyalty. The arguments mentioned above leave no doubt about the issue of selecting the concept of loyalty; unambiguously, it is the behavioural loyalty together with the influence of attitudinal loyalty, which becomes evident during the loyalty formation (Fig. 1). 


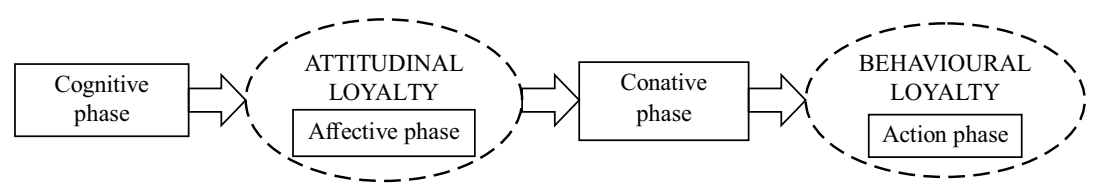

Fig. 1. The place of loyalty dimensions in the cycle of loyalty formation

Scientists (Casalo et al. 2007; Chao 2008; Liu et al. 2012) repetitively mention the elements of customer loyalty towards a service provider, i.e. the frequency of purchases and the value of purchases. A joint analysis of indicators for loyalty, i.e. the value of purchases and the frequency of purchases, is significant as both indicators reveal two different aspects essential for measuring loyalty: the number of purchases and financial resources allocated to the provider of a service (Bodet, Bernache-Assollant 2011; Quoquab et al. 2014). Therefore, it is suggested to measure loyalty taking into account the combination of indicators for the frequency of purchases and the value of purchases.

The above-mentioned arguments allow the concept of loyalty to be treated as the construct that covers the frequency of purchases and the value of purchases. It is suggested to define loyalty by using the model presented in equation (1):

$$
L_{i j k}=f\left(v_{i j k}, d_{i j k}\right) \text {, }
$$

where $L$ is loyalty; $v$ is the value of purchases; $d$ is the frequency of purchases; $i$ is a customer $(i=1,2, \ldots, m) ; j$ is the type of a service $(j=1,2, \ldots, n) ; k$ is a service provider $(k=1,2, \ldots, p)$.

Given the variety of customers in accordance with the extent and pattern of their consumption of services, it is purposeful to base the measurement of loyalty on ratios, i.e. the value and frequency of the purchase will be transformed into ratios. This is made through the application of normalisation procedures presented in equations (2) and (3):

$$
\begin{gathered}
v_{i j k}=\frac{V_{i j k}}{\sum_{k} V_{i j k}} ; \\
d_{i j k}=\frac{D_{i j k}}{\sum_{k} D_{i j k}},
\end{gathered}
$$

where $V_{i j k}$ is the value of the purchases of the $i$-th customer of the $j$-th type of the service from the $k$-th provider (the absolute value); $D_{i j k}$ is the frequency of the purchases of the $i$-th customer of the $j$-th type of the service from the $k$-th provider (the absolute value).

\subsection{Weights of elements}

The impact of the elements of customer loyalty towards a service provider on the loyalty estimator is not equal. The results of the studies carried out for the period 1968-2012 (Sheth 1968; Guenzi, Pelloni 2004; Allaway et al. 2006; Chen, Hitt 2006; Keiningham 2007; Casalo et al. 2007; Chao 2008; Huang 2008; Carlson, O'Cass 2012) reveal that the frequency of purchases and the value of purchases differently affect customer loyalty (Table 1). 
Table 1. Correlation between loyalty, the frequency of purchases and the value of purchases

\begin{tabular}{lcc}
\multicolumn{1}{c}{ Authors } & $\begin{array}{c}\text { Correlation between loyalty } \\
\text { and the frequency of } \\
\text { purchases }\end{array}$ & $\begin{array}{c}\text { Correlation between loyalty } \\
\text { and the value of purchases }\end{array}$ \\
\hline J. N. Sheth (1968) & 1.00 & - \\
\hline P. Guenzi, O. Pelloni (2004) & 0.088 & - \\
\hline A. W. Allaway et al. (2006) & - & 0.839 \\
\hline S. C. Chen, L. M. Hitt (2006) & 0.80 & 0.84 \\
\hline T. L. Keiningham (2007) & - & 0.17 \\
\hline V. Casalo et al. (2007) & 0.411 & - \\
\hline P. Chao (2008) & 0.714 & - \\
\hline L. Huang (2008) & 0.69 & 0.658 \\
\hline J. Carlson, A. O'Class (2012) & 0.173 & - \\
\hline Average & 0.554 & 0.627 \\
\hline
\end{tabular}

In order to measure the significance of the frequency of purchases and the value of purchases, the averages were equalled to 1 . It was estimated that the frequency of purchases determined 47 per cent of loyalty, and 53 per cent stemmed from the value of purchases. The significance of loyalty elements is rather universal. However, this significance can be revised by carrying out target research adapted to the specific type of the service.

\subsection{Period}

Loyalty towards a service provider is measured according to customer behaviour during a specific period $(t)$. The definition of the period necessary to measure customer loyalty towards a service provider should start with the identification of the analysed service sector. Then, it is possible to decide if the service is attributable to the category of frequently or rarely used services. Purchasing trends have been insufficiently studied both theoretically and empirically in separate sectors so far, which has supposed the need to prepare classification comprising different types of services (Table 2).

The frequency of services is usually measured by the inter-purchase cycle (Wheat, Morrison 1990; Chintagunta, Haldar 1998). Therefore, the inter-purchase cycle for each service has been calculated. The duration of the inter-purchase cycles of services differs significantly in separate sectors. Therefore, it is suggested to divide all services into categories according to frequency and to divide all values of the inter-purchase cycle to quartiles (Fig. 2.).

A period of 2 years is applied when measuring loyalty towards rarely used services. The entire available history of purchasing is required to study the customer loyalty towards very rarely used services. If the organisation possesses data on the inter-purchase cycle of the customers, its average value is calculated, and the period is selected according to its interval. 
Table 2. The frequency of using the inter-purchase cycle of services in separate sectors

\begin{tabular}{|c|c|c|c|c|}
\hline Services & Authors & Period & $\begin{array}{l}\text { Average } \\
\text { frequency, } \\
\text { occasions }\end{array}$ & $\begin{array}{l}\text { Inter- } \\
\text { purchase } \\
\text { cycle, days }\end{array}$ \\
\hline \multirow[t]{3}{*}{ Banks } & M. Lee, L. F. Cunningham (2001) & Month & 7.8 & 6.42 \\
\hline & P. N. Thuy, L. N. Hau (2010) & 3 months & 9.17 & \\
\hline & L. Skowron, K. Kristensen (2012) & Month & 3.36 & \\
\hline $\begin{array}{l}\text { Travel } \\
\text { agencies }\end{array}$ & M. Lee, L. F. Cunningham (2001) & 6 months & 4.6 & 39.67 \\
\hline Air transport & K. Q. V. Pham, M. Simpson (2006) & Year & 2.59 & 140.93 \\
\hline $\begin{array}{l}\text { Beauty salons } \\
\text { and stylist } \\
\text { services }\end{array}$ & L. L. Bove, L. W. Johnson (2009) & 6 months & 5.22 & 34.96 \\
\hline Hotels & H. Osman et al. (2009) & $\begin{array}{l}\text { Year (number } \\
\text { of days) }\end{array}$ & 40.23 & 907 \\
\hline Restaurants & M. A. Clark, R. C. Wood (1999) & Month & 3.96 & 7.68 \\
\hline Theatres & O. Guillon (2011) & Three seasons & 2.4 & 456.25 \\
\hline \multicolumn{2}{|c|}{3 months 12 months } & \multicolumn{3}{|c|}{ Entire available purchasing history } \\
\hline \begin{tabular}{l|lll}
0 & 1 & 8 & \\
1 & $\downarrow$ & & $\downarrow$
\end{tabular} & \begin{tabular}{|}
35 \\
$\downarrow$
\end{tabular} & \multicolumn{2}{|c|}{$\nabla$} & 456 \\
\hline $\begin{array}{c}\begin{array}{c}\text { Used } \\
\text { very } \\
\text { frequently }\end{array} \\
\text { freque }\end{array}$ & Used rarely & \multicolumn{2}{|c|}{ Used very rarely } & \\
\hline
\end{tabular}

Fig. 2. The classification of services according to the inter-purchase cycle in days

\subsection{Options for measuring customer loyalty}

Loyalty will be measured in regard to a particular type of the service provided by a particular organisation in accordance with the behaviour of customers during a particular period of time $(t)$, which means that the array of data necessary for measuring loyalty must include figures on the value and frequency of the purchases of every customer. This data must show information about the purchases of a particular type of the service from the analysed service provider $\left(v_{i j k}\right.$ and $\left.d_{i j k}\right)$ and the purchases from other providers of the same service. Possible situations of data availability lead to three different options for measuring customer loyalty (Fig. 3).

Option 1 provides a possibility of obtaining all data. The following options for gaining all data are considered: consumption data (provided by the customer) or business data (provided by the company). With reference to the data, the relative value of purchases and the frequency of purchases are calculated. The values of the introduced indexes approximating to 1 show that the customer is strongly linked to the use of services $j$ of the $k$-th service provider and is not interested in any other options. The offered alternative to measuring the customer loyalty causes the least trouble with regards to financial and time cost aspects. 


\begin{tabular}{|c|c|c|c|c|}
\hline \multicolumn{5}{|c|}{ Customer loyalty measurement } \\
\hline 5 & \multicolumn{2}{|r|}{$\leq 2$} & \multicolumn{2}{|c|}{ S } \\
\hline $\begin{array}{c}\text { I. A possibility of } \\
\text { obtaining all data }\left(v_{i j k} \text { and }\right. \\
d_{i j k} \text { in accordance with all } k \text { ) }\end{array}$ & \multicolumn{2}{|c|}{$\begin{array}{l}\text { II. Only } v_{i j k} \text { and } d_{i j k} \text { of the } \\
\text { analysed organisation are } \\
\text { known, } k=1\end{array}$} & \multicolumn{2}{|c|}{$\begin{array}{l}\text { III. } v_{i j k} \text { and } d_{i j k} \\
\text { are unknown, when } k=1 \\
\text { (of the analysed } \\
\text { organisation) }\end{array}$} \\
\hline$\downarrow$ & $\downarrow$ & $\downarrow$ & $\downarrow$ & $\downarrow$ \\
\hline $\begin{array}{c}v_{i j}=\sum_{k} v_{i j k}, d_{i j}=\sum_{k} d_{i j k} \\
\text { (statistical data: consumption } \\
\text { or business data) }\end{array}$ & $\begin{array}{l}\text { Marketing } \\
\text { researches }\end{array}$ & $\begin{array}{l}\text { Available data on } \\
\text { the organisation } \\
\text { (the principle of } \\
\text { analogy is applied) }\end{array}$ & \begin{tabular}{|c|} 
The \\
measurement \\
of loyalty \\
drivers
\end{tabular} & $\begin{array}{c}\text { A } \\
\text { questionnaire } \\
\text { survey }\end{array}$ \\
\hline
\end{tabular}

Fig. 3. Options for measuring customer loyalty

Option 2 refers to the situation when only data on the frequency of the purchases and values of the investigated organisation are known. Service organisations tend to register data on the frequency and value of purchases in databases (O'Malley 1998); however, accessibility to information about the frequency and value of purchases in other organisations that provide the same services can be limited. When accessibility to such data is insufficient, slightly increased financial resources for measuring customer loyalty must be allocated. $v_{i j k}$ and $d_{i j k}$ must be measured through the application of heuristic algorithms in accordance with $v_{j k}, v_{i k}, v_{i j k}, d_{j k}, d_{i k}, d_{i j k}$. For this purpose, marketing research must be carried out or data available in the organisation will be applied (through the application of the principle of analogy). For receiving data on the frequency and values of purchases made from other organisations providing certain services, the principle of analogy is applied and covers the results of other empirical research (1), the values and frequency of the other service provided by the organisation or other provider offering the $j$-th service (2).

Option 3 suggests that if data on the frequency and value of the purchases of the analysed organisation are unknown, loyalty drivers will be identified and measured. Customer loyalty is determined by a wide spectrum of drivers. The problems arise when the exact set of the drivers determining customer loyalty is unknown. Such set includes:

- customer drivers (age, gender, income, social status, switching costs);

- service provider drivers (assortment, innovations, additional services, personalization, service life cycle, price, quality, location, business hours, marketing, shopping atmosphere, reputation, customer service, payment system, personnel qualification);

- environmental drivers (competition, economic development, social support).

The set of the drivers must be systematised, and, therefore, scales have to be applicable in order to measure each driver.

In the case of a shortage of data necessary for measuring the drivers, a survey required for obtaining information about probable loyalty has to be conducted. Various methods of surveying, including a questionnaire survey, interview, expert survey, etc. are applicable in order to measure probable loyalty. Every type of surveying has shortcomings limiting its applicability when measuring probable loyalty. A questionnaire survey is the least disadvantageous of all surveying methods and provides the broadest possibilities of applying probable loyalty. In practice, it is treated as a convenient way to collect 
the required information. Therefore, this type of surveying is popular when conducting research on customer loyalty towards a service provider (Chen, Cheng 2012; Khan, Fasih 2014; Yang et al. 2014).

Options for measuring customer loyalty differ in their range and requirements for information provision. All options have one common characteristic - they allow measuring customer loyalty towards a service provider based on the created system of measures.

\subsection{Stages of customer loyalty}

The measurement of customer loyalty towards a service provider allows dividing it into four stages (Fig. 4.):

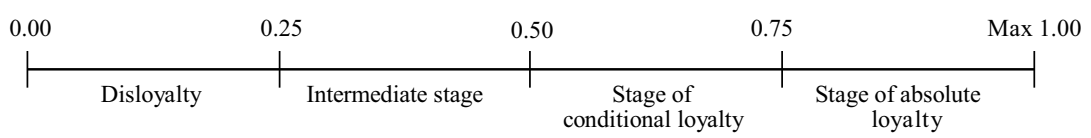

Fig. 4. Scale of measuring customer loyalty towards a service provider

Customer loyalty towards a service provider is divided into stages of disloyalty, intermediate stage, conditional loyalty and absolute loyalty. The stages of disloyalty and absolute loyalty are explicitly described in the academic and professional literature (Pileliene et al. 2009; Worthington et al. 2010). The customers at the intermediate stage have not made a decision yet, they are choosing, contemplating and can change their stage at any time and not necessarily to the one of stronger loyalty. The stage of conditional loyalty is achieved when the loyalty estimator exceeds the average $(0.5)$ but the customers of the service sector are not absolutely loyal yet. The stage of absolute loyalty is the result of the effective development of customer loyalty in the service organisation. The measurement of the customer loyalty stage shows if the measures used for developing loyalty have been correctly chosen and if their implementation has been successful.

\section{Empirical study}

\subsection{Research methodology}

The methodology of the empirical application of the model for measuring customer loyalty is designed for service organisations irrespective of their size, geographical location, specificity and the number of customers. The algorithm for measuring customer loyalty is provided in Figure 5.

The main actions performed during the measurement of customer loyalty are as follow:

- definition of the general characteristics of the service provider;

- definition of the period necessary for measuring customer loyalty towards a service provider;

- assessment of data accessibility and selection of the most suitable option for measuring customer loyalty;

- measurement of the stage of customer loyalty towards a service provider. 


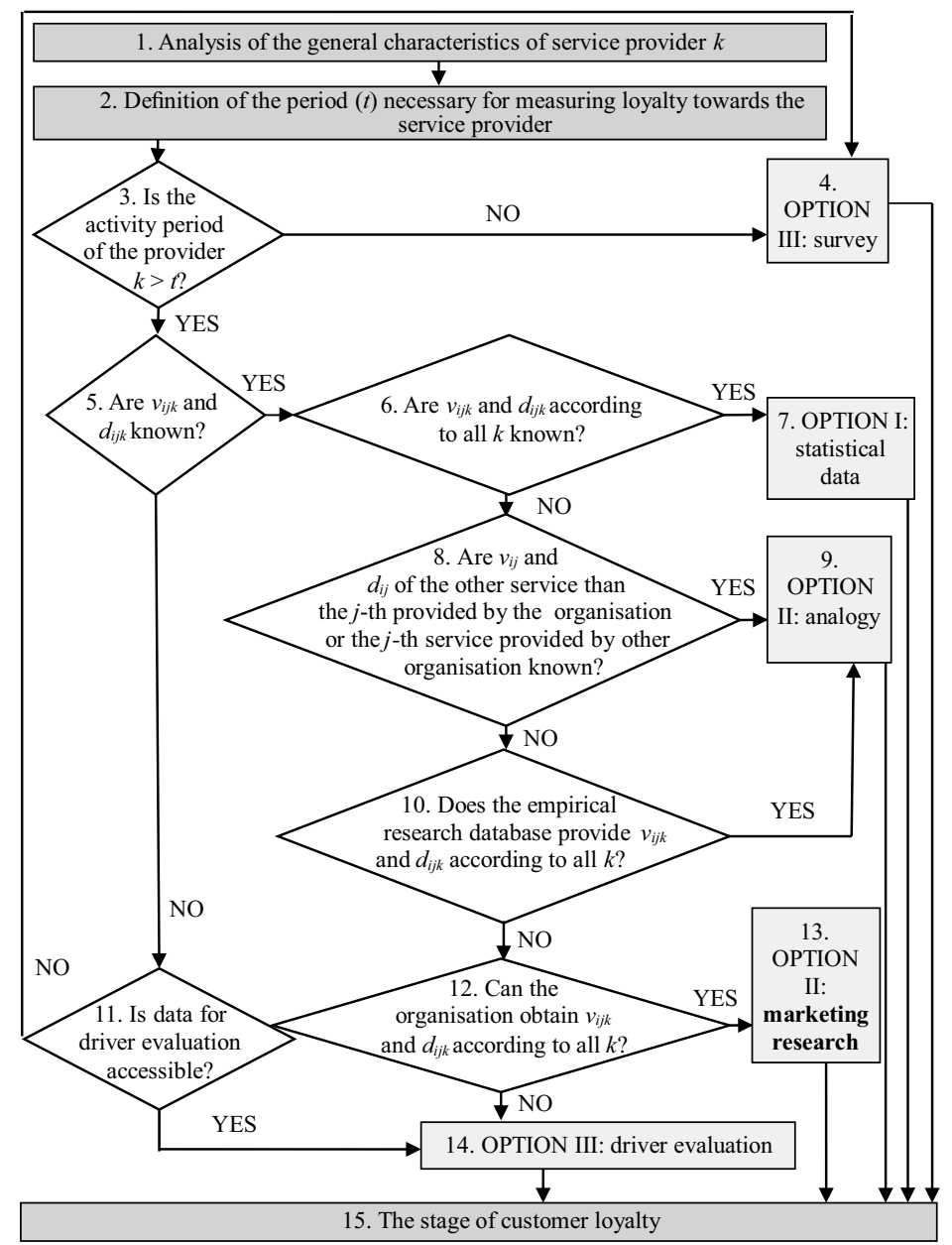

Fig. 5. Algorithm for measuring customer loyalty towards a service provider

The measurement of customer loyalty is commenced by performing the analysis of the general characteristics of the service provider.

The definition of the period necessary for measuring customer loyalty is commenced by calculating the inter-purchase cycle; if the organisation does not have any data on the frequencies of purchases, the cycles provided in Table 2 are to be used.

The most suitable option for measuring customer loyalty is selected according to data accessibility (Fig. 5). A situation is possible when data accessibility allows measuring customer loyalty using any of the available options. In such a case, the rule of selecting the first option and sub-option is applicable.

When the first option of measuring customer loyalty towards a service provider is applied, relative frequencies, the values of purchases and loyalty estimators are calculated. Once the loyalty of each customer is estimated, they are classified into four stages of disloyalty, the intermediate stage, conditional loyalty and absolute loyalty. 
The measurement of customer loyalty using the second option is carried out in an analogical way. However, depending on the available data array, additional actions such as the calculation of data on the frequency and the value of purchases considering sales or the recalculation of frequencies and values during the period $t$ may be required.

If customer loyalty is measured using the third option, the drivers are evaluated or the questionnaire survey is conducted. Calculations are carried out (irrespective of the situation on data accessibility and the selected option) using SPSS or other software.

\subsection{Empirical results}

For empirical research, a catering company located in Šiauliai city (Lithuania) and owning a restaurant has been chosen. The restaurant is managed by a private limited liability company registered on 23 February 2012. The company has 9 employees and creates plans for developing its catering business in the future by establishing new restaurants in Lithuania and broadening the range of provided services.

The measurement of customer loyalty starts with the definition of the research period. According to Table 1, the inter-purchase cycle of catering services is equal to 7.68 days, which means that the services provided by the restaurant are very frequently used, and a period of 3 months is applicable in order to measure the loyalty of customers using these services. To determine customer loyalty, data on 219 participants in the loyalty programme for the period from 1 May 2014 to 31 July 2014 have been used.

The company enabled the researcher to gain all required data in order to measure the loyalty of the customers of the analysed restaurant. The gathered data array allowed evaluating customer loyalty using any of the three options of the created model. Under such circumstances, it is recommended to follow the rule of the prioritised option; therefore, the first one has been chosen. The main source of data on measuring customer loyalty was a customer loyalty programme of the restaurant. The following data was sorted out: the frequency and value of the purchases of every customer in the restaurant and the frequency and value of the purchases of every customer in the catering industry. Only data for the period of 3 months was required.

Pursuant to data on the frequency and value of the purchases of the customers of the analysed restaurant, the relative frequency and value of purchases for every unique visitor have been calculated and the values of the loyalty index have been obtained. It has been also established that the values of the loyalty index of restaurant visitors amount to $0.05-1.00$, with the average of 0.46 . According to the average value of the loyalty index, the loyalty of restaurant customers is intermediate. The distribution of all visitors shows that the loyalty of as much as 66.21 per cent of the customers of the restaurant is of the intermediate stage. Somewhat stronger loyalty is demonstrated by 17.35 per cent of visitors. 11.42 per cent of visitors are attributed to the stage of absolute loyalty and 5.02 per cent of those are considered disloyal.

The empirical research allowed confirming the validity, suitability and efficiency of the suggested model for measuring customer loyalty towards a service provider in terms of time consumption. The regular use of the model by the catering organisation while fol- 
lowing changes in the estimator of customer loyalty towards a service provider would perform the function of loyalty monitoring. Depending on the results obtained using the suggested model for measuring customer loyalty towards a service provider and the sought loyalty estimator, executives and management specialists at service organisations can plan adequate means that would allow expecting higher customer loyalty towards a service provider in the future.

\section{Conclusions}

The study introduces an innovative attitude to measuring customer loyalty towards a service provider. The suggested model for measuring customer loyalty eliminates the problems that arise due to disagreements with regard to the concept and elements of loyalty and to variety in the treatment of their significance. The suggested model for measuring customer loyalty creates the background for selecting the optimum research period and individualising the measurement of customer loyalty according to data accessibility situations. In addition, the model details the contents of the set of customer loyalty drivers and their impact on loyalty.

The suggested concept of measuring customer loyalty towards a service provider allows the researcher to evaluate loyalty pursuant to the concept of behavioural loyalty (with the impact of attitudinal loyalty manifesting itself during the stage of forming emotional loyalty). The application of this concept provides a broad solution to the relevant scientific problem with reference to available data on the frequency and value of the purchases of service sector customers. Moreover, loyalty measurement based on the past behaviour of customers provides a solid ground to forecast customer behaviour in the future.

The paper presents a new attitude towards measuring the customer loyalty of the service organisation thus creating the background for the selection of the optimum research period. Depending on data accessibility, three alternatives for measuring customer loyalty towards a service provider have been suggested. Loyalty measurement according to data on business and consumption is considered as the most superior, when precision, demand of financial, time, and human resources as well as reliability and objectivity is analysed. If limitations on market data acquisition exist, marketing research is carried out or the analogy is used. The third alternative is based upon the measurement of loyalty drivers or a questionnaire survey.

The practical acceptability of the suggested model for measuring customer loyalty towards a service provider has been tested by conducting a case study. The results of this research allowed recording the economic efficiency of the model in terms of time consumption and its suitability for the use in situations when access to data on the frequency and value of purchases is not limited.

The practical implications of this study are clearly applicable to the Lithuanian catering industry, in which companies will find it extremely useful to follow the proposed model for measuring the customer loyalty, since the results of applying the model reveal the 
factual or probable stage of customer loyalty. Depending on the results of investigated customer loyalty, executives and management specialists in catering business can plan adequate means that would allow expecting higher customer loyalty towards a service provider in the future.

Empirical tests on the model have some limitations related to the region or size of the service provider chosen for the case study. Additionally, the authors have focused on catering industry only. The practical acceptability of the model for measuring customer loyalty in other service sectors could be tested in order to examine Options 2 and 3. Since the flexible structure of the model allows adapting it to various services and different situations on data accessibility, future research lines will be more focused on measuring customer loyalty in other types of industries (banks, travel agencies, hotels, etc.).

\section{References}

Allaway, A. W.; Gooner, R. M.; Berkowitz, D.; Davis, L. 2006. Deriving and exploring behaviour segments within a retail loyalty card program, European Journal of Marketing 40(11/12): 1317-1339. http://dx.doi.org/10.1108/03090560610702830

Bennett, R.; Rundle-Thiele, S. 2002. A comparison of attitudinal loyalty measurement approaches, Brand Management 9(3): 193-209. http://dx.doi.org/10.1057/palgrave.bm.2540069

Bodet, G.; Bernache-Assollant, I. 2011. Consumer loyalty in sport spectatorship services: the relationships with consumer satisfaction and team identification, Psychology \& Marketing 28(8): 781-802. http://dx.doi.org/10.1002/mar.20412

Bove, L. L.; Johnson, L. W. 2009. Does "true" personal or service loyalty last? A longitudinal study, Journal of Services Marketing 23(3): 187-194. http://dx.doi.org/10.1108/08876040910955198

Calin, G. 2013. Factors influencing customer behaviour towards trusted service providers: an investigation of four service settings, Annals of the University of Oradea, Economic Science Series 22(1): 1753-1764.

Carlson, J.; O'Cass, A. 2012. Optimizing the online channel in professional sport to create trusting and loyal customers: the role of the professional sports team brand and service quality, Journal of Sport Management 26: 463-478.

Casalo, L.; Flavian, C.; Guinaliu, M. 2007. The impact of participation in virtual brand communities on consumer trust and loyalty. The case of free software, Online Information Review 31(6): 775-792. http://dx.doi.org/10.1108/14684520710841766

Chadha, S. K.; Kapoor, D. 2009. Effect of switching cost, service quality and customer satisfaction on customer loyalty of cellular service providers in Indian market, The Icfai University Journal of Marketing Management 8(1): 23-37.

Chao, P. 2008. Exploring the nature of the relationships between service quality and customer loyalty: an attribute-level analysis, The Service Industries Journal 28(1): 95-116.

http://dx.doi.org/10.1080/02642060701725610

Chen, C. F.; Cheng, L. T. 2012. A study on mobile phone service loyalty in Taiwan, Total Quality Management 23(7): 807-819. http://dx.doi.org/10.1080/14783363.2012.661129

Chen, P. Y.; Hitt, L. M. 2006. Measuring switching costs and the determinants of customer retention in internet-enabled businesses: a study of the online brokerage industry, Information Systems Research 13(1): 255-274.

Chintagunta, P. K.; Haldar, S. 1998. Investigating purchase timing behaviour in two related product categories, Journal of Marketing Research 35: 43-53. http://dx.doi.org/10.2307/3151929 
Chou, P. F.; Lu, C. S.; Chang, Y. H. 2014. Effects of service quality and customer satisfaction on customer loyalty in high-speed rail services in Taiwan, Transportmetrica 10(10): 917-945. http://dx.doi.org/10.1080/23249935.2014.915247

Clark, M. A.; Wood, R. C. 1999. Consumer loyalty in the restaurant industry. A preliminary exploration of the issues, British Food Journal 101(4): 317-326.

http://dx.doi.org/10.1108/00070709910272196

Dick, A.; Basu, K. 1994. Customer loyalty: towards an integrated framework, Journal of Academy of Marketing Science 22: 99-113. http://dx.doi.org/10.1177/0092070394222001

El-Manstrly, D.; Harrison, T. 2013. A critical examination of service loyalty measures, Journal of Marketing Management 29(15/16): 1834-1861. http://dx.doi.org/10.1080/0267257X.2013.803139

Guenzi, P.; Pelloni, O. 2004. The impact of interpersonal relationships on customer satisfaction and loyalty to the service provider, International Journal of Service 15(4): 365-384.

http://dx.doi.org/10.1108/09564230410552059

Guillon, O. 2011. Loyalty behaviours and segmentation of performing arts audiences: the case of Theatre de 1'Athenee in Paris, International Journal of Arts Management 14: 32-44.

Hart, S.; Smith, A.; Sparks, L.; Tzokas, N. 1999. Are loyalty schemes a manifestation of relationship marketing?, Journal of Marketing Management 15: 541-562.

http://dx.doi.org/10.1362/026725799785045842

Huang, L. 2008. Exploring the determinants of e-loyalty among travel agencies, The Service Industries Journal 28(2): 239-254. http://dx.doi.org/10.1080/02642060701842316

Keiningham, T. L. 2007. The value of different customer satisfaction and loyalty metrics in predicting customer retention, recommendation, and share-of-wallet, Managing Service Quality 17(4): 361-384. http://dx.doi.org/10.1108/09604520710760526

Khan, M. M.; Fasih, M. 2014. Impact of service quality on customer satisfaction and customer loyalty: evidence from banking sector, Pakistan Journal of Commerce and Social Sciences 8(2): 331-354.

Kumar, V.; Sharma, A.; Shah, R.; Rajan, B. 2013. Establishing profitable customer loyalty for multinational companies in the emerging economies: a conceptual framework, Journal of International Marketing 21(1): 57-80. http://dx.doi.org/10.1509/jim.12.0107

Lee, M.; Cunningham, L. F. 2001. A cost/benefit approach to understanding service loyalty, Journal of Services Marketing 15(2): 113-130. http://dx.doi.org/10.1108/08876040110387917

Liu, M.; Brock, J.; Singh, R.; Chu, R.; Sy-Changco, J. 2012. What drives Indian consumer credit card loyalty? The perspective of involvement in reward programmes, International Review of Retail, Distribution \& Consumer Research 4: 365-383. http://dx.doi.org/10.1080/09593969.20 12.690776

Narteh, B. 2013. Determinants of student loyalty in the Ghanaian banking industry, The TQM Journal 25(2): 153-169. http://dx.doi.org/10.1108/17542731311299591

Oliver, R. L. 1999. Whence consumer loyalty?, Journal of Marketing 63: 33-44.

http://dx.doi.org/10.2307/1252099

Osman, H.; Hemmington, N.; Bowie, D. 2009. A transactional approach to customer loyalty in the hotel industry, International Journal of Contemporary Hospitality Management 21(3): 239-250. http://dx.doi.org/10.1108/09596110910948279

Pham, K. Q. V.; Simpson, M. 2006. The impact of frequency of use on service quality expectations: an empirical study of trans-Atlantic airline passengers, The Journal of American Academy of Business 10(1): 1-6.

Pilelienè, L.; Zikienè, K.; Švagždienè, B. 2009. The formation of customer loyalty conception in the context of the evolution of schools of marketing thought, Social Research 2(16): 67-76. 
Quoquab, F.; Yasin, N. M.; Dardak, R. A. 2014. A qualitative inquiry of multi-brand loyalty, Asia Pacific Journal of Marketing and Logistics 26(2): 250-271.

http://dx.doi.org/10.1108/APJML-02-2013-0023

Reinartz, W.; Thomas, J. S.; Bascoul, G. 2008. Investigating cross-buying and customer loyalty, Journal of Interactive Marketing 22(1): 5-20. http://dx.doi.org/10.1002/dir.20106

Roy, S. 2011. Brand loyalty measurement: a framework, SCMS Journal of Indian Management 8(2): $112-122$.

Seto-Pamies, D. 2012. Customer loyalty to service providers: examining the role of service quality, customer satisfaction and trust, Total Quality Management 23(11): 1257-1271.

http://dx.doi.org/10.1080/14783363.2012.669551

Sheth, J. N. 1968. A factor analytical model of brand loyalty, Journal of Marketing Research 5: 395-404. http://dx.doi.org/10.2307/3150264

Skowron, L.; Kristensen, K. 2012. The impact of the recent banking crisis on customer loyalty in the banking sector. Developing versus developed countries, The TQM Journal 24(6): 480-497. http://dx.doi.org/10.1108/17542731211270052

Terblanche, N. S.; Boshoff, C. 2010. Quality, value, satisfaction and loyalty among race groups: a study of customers in the South African fast food industry, South African Journal of Business Management 41(1): 1-9.

Thuy, P. N.; Hau, L. N. 2010. Service personal values and customer loyalty. A study of banking services in a transitional economy, International Journal of Bank 28(6): 465-478.

http://dx.doi.org/10.1108/02652321011077706

Topcu, B.; Duygun, A. 2015. The impacts of customer loyalty on negative word-of-mouth communication and repurchase intention, Journal of Marketing and Management 6(1): 16-27.

Tuu, H. H.; Olsen, S. O. 2010. Nonlinear effects between satisfaction and loyalty: an empirical study of different conceptual relationships, Journal of Targeting, Measurement and Analysis for Marketing 18(3/4): 239-251. http://dx.doi.org/10.1057/jt.2010.19

Uncles, M. D.; Wang, C.; Kwok, S. 2010. A temporal analysis of behavioural brand loyalty among urban Chinese consumers, Journal of Marketing Management 26(9-10): 921-942.

http://dx.doi.org/10.1080/02672570903441454

Wheat, R. D.; Morrison, D. G. 1990. Assessing purchase timing models: whether or not is preferable to when, Marketing Science 9(2): 162-170. http://dx.doi.org/10.1287/mksc.9.2.162

Worthington, S.; Russell-Bennett, R.; Hartel, C. 2010. A tri-dimensional approach for auditing brand loyalty, Brand Management 17(4): 243-253. http://dx.doi.org/10.1057/bm.2009.24

Yang, C. C.; Chen, P. S.; Chien, Y. H. 2014. Customer expertise, affective commitment, customer participation, and loyalty in B\&B services, International Journal of Organizational Innovation 6(4): 174-183.

Yong-Jae, P.; Hwan-Myung, R.; Seung-Koog, L. 2013. Factors affecting customer loyalty of mobile RFID services in Korea, Technological \& Economic Development of Economy 19(4): 687-705. http://dx.doi.org/10.3846/20294913.2013.837413

Zhang, H.; Fu, X.; Cai, L. A.; Lu, L.2014. Destination image and tourist loyalty: a meta-analysis, Tourist Management 40: 213-223. http://dx.doi.org/10.1016/j.tourman.2013.06.006 
Ilona SKAČKAUSKIENĖ. Doctor of Social Sciences, Associate Professor, Head of the Dept of Social Economics and Management, Vilnius Gediminas Technical University. She has published over 30 publications and presented reports in Lithuanian and international conferences. Her research interests: taxation, tax system evaluation, budget revenue formation, social and economic development.

Neringa VILKAITE்-VAITONE். Doctor of Social Sciences, the Dept. of Social Economics and Management, Vilnius Gediminas Technical University. She has published over 10 publications concerning customer loyalty and its measurement. Her research interests: customer loyalty, service business, marketing planning, integrated marketing communications.

Sergej VOJTOVIC. Doctor of Social Sciences, Professor, the Dept. of Management and Development of Human Resources, the University of Alexander Dubcek in Trencin. He has published more than 145 scientific publications in Slovakia and abroad (Austria, China, Czech Republic, Germany, Lithuania, Poland, Russia, Serbia, Ukraine). His research interests: marketing research, human resources management, personnel management, microeconomic regularities of economic development, economic sociology, labour market, mobility and labour force migration. 